\title{
Three species of the jumping spiders (Araneae: Salticidae: Nungia, Pancorius and Thyene) new to Japan
}

\author{
Hiroyoshi Ikeda \\ Kanade 1099, Oi-machi, Ashigarakami-gun, Kanagawa Pref., 258-0018 Japan \\ E-mail: mail2-ikeda@nifty.com
}

\begin{abstract}
Three species of jumping spiders, Nungia epigynaris Żabka 1985, Pancorius submontanus Prószyński 1992 and Thyene orientalis Żabka 1985, all of them new to Japanese fauna, are redescribed on the basis of specimens collected from the Ryukyu Islands. The female of Thyene orientalis Żabka 1985 is described for the first time.
\end{abstract}

Key words - Salticidae, Nungia, Pancorius, Thyene, Japan

Recently, I found three formerly unrecorded species from Japan in the specimens collected from the Ryukyu Islands, Japan, which are described here. Of these, the genus Nungia is new to Japanese fauna. The female of Thyene orientalis Żabka 1985 is described for the first time.

The specimens used for this study are deposited in the collection of the Department of Zoology, the National Museum of Nature and Science, Tokyo.

The following abbreviations are used: ALE, anterior lateral eye; AME, anterior median eye; $p$, prolateral; PLE, posterior lateral eye; PME, posterior median eye; $r$, retrolateral. ALE-PME length was measured from the anterior margin of the anterior lateral eye to the posterior margin of the posterior median eye in dorsal view. All measurements are in $\mathrm{mm}$.

\section{Genus Nungia Żabka 1985}

Type species: Nungia epigynaris Żabka 1985.

This genus is monotypic. The female holotype of this type species has a butterfly-shaped internal structure thickly walled in epigynum; prosoma is strongly flattened; opisthosoma is elongate with longitudinal pigment streaks (Żabka 1985). Male prosoma and opisthosoma are same as those of female. The embolus basement of male palp is broad as tegulum, retrolateral tibial apophysis is robust.

\section{Nungia epigynalis Żabka 1985 \\ [Japanese name: Okuma-haetori]}

(Figs. 1-8)

Nungia epigynalis Żabka 1985, p. 421, figs. 378-380 (ㅇ); Peng, Xie \& Xiao 1993, p. 143, figs. 495-504 (구우); Song et al. 1999, p. 536, figs. 305V (क palp), 306B (क epigynum), $327 \mathrm{O}$ (ㅇ body).
Specimens examined. Ishigakijima Island, Okinawa

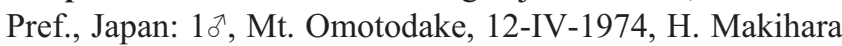
leg. (NSMT-Ar 12510); 1우, same locality, 14-X-1963, Y. Hirashima leg. (NSMT-Ar 12511); 1우, Mt. Kawarayama, 28-X-1963, Y. Hirashima leg. (NSMT-Ar 12514). Iriomotejima Island, Okinawa Pref., Japan: 10, Komi, 29III-1988, A. Tanikawa leg. (NSMT-Ar 12512); 1우 2 nymphs, same locality, 11-IV-1974, H. Makihara leg. (NSMT-Ar 12513); 1우, Ohara, 12-VIII-1985, A. Tanikawa leg. (NSMT-Ar 12515); 1우, Shirahama, 27-XII-1987, A. Tanikawa leg. (NSMT-Ar 12516).

Comparative material. Bavia sexpunctata (Doleschall 1859). 1 $\widehat{\delta}^{\lambda}$, Iriomotejima Island, 29-III-1985, A. Tanikawa leg; 1우, same locality and collector, 27-III-1985.

Description. A male (NSMT-Ar 12510) and a female (NSMT-Ar 12511), both from Ishigakijima Island.

Male. Body length 5.07; prosoma length 2.42, width 1.92 , height 1.25 ; opisthosoma length 2.67 , width 1.25 . Eye fields: width of eye row I 1.67, width of eye row III 1.74 , length of eye row 1.09, ALE-PME length 0.53, AME diameter 0.85; ratio ALE/AME 0.56, ALE/PLE 1.03, PME/PLE 0.29. Length and spination of legs as shown in Tables 1 and 2 respectively. Leg III longest.

Coloration and markings (Fig. 1). Prosoma shiny dark brown and surroundings of eyes black with brown setae and white hairs. Clypeus, maxillae, labium and sternum brown. Opisthosomal dorsum in ethanol yellowish brown and two black streaks with brown setae and brown hairs, especially many brown setae on anterior margin. Spinnerets dark brown. Venter of opisthosoma gray, stained blackly and with a pair of longitudinal orange lines on anterior half. All legs orange brown except for dark brown femora and tibiae of leg I.

Chelicera (Fig. 3) with promarginal two teeth and several dents (seven in NSMT-Ar 12510), retromarginal single tooth. 

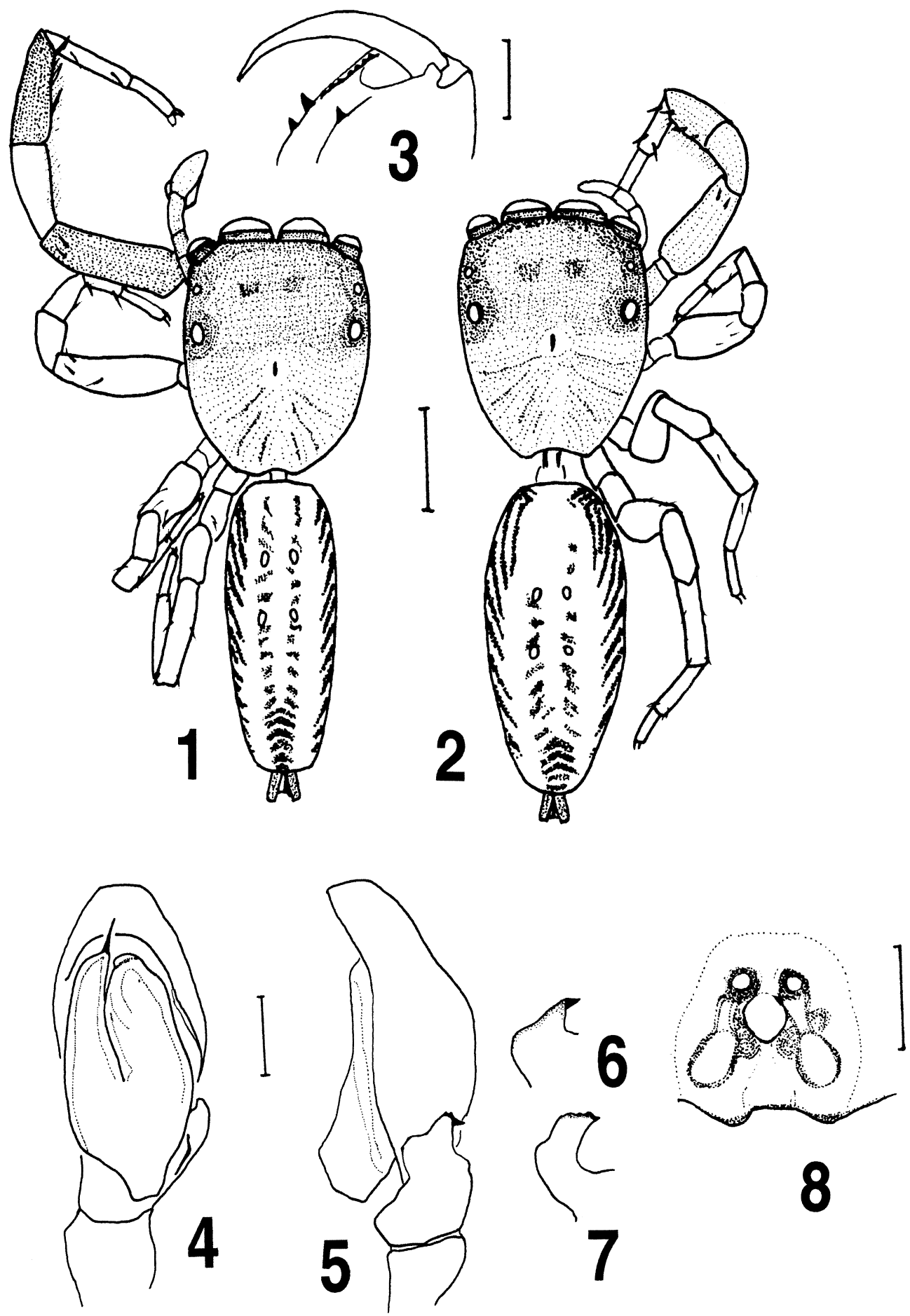

8

Figs. 1-8. Nungia epigynalis Żabka 1985, male (1,3-7, NSMT-Ar 12510) and female (2, 8, NSMT-Ar 12511) from Mt. Omotodake, Ishigakijima Island. 1-2, habitus, dorsal views; 3 , left chelicera, showing cheliceral teeth, ventral view; 4-5, left palp, ventral (4) and retrolateral (5) views; 6-7, retrolateral tibial apophysis of palp, lateral (6) and dorsal (7) views; 8, epigynum, ventral view. Scales $=1.0 \mathrm{~mm}$ $(1-2) ; 0.2 \mathrm{~mm}(3-8)$.

Table 1. Length of leg segments of Nungia epigynalis [ð (NSMT-Ar 12510)/ㅇ(NSMT-Ar 12511), in mm].

\begin{tabular}{ccccccc}
\hline Leg & Femur & Patella & Tibia & Metatarsus & Tarsus & Total \\
\hline I & $1.09 / 0.87$ & $0.68 / 0.57$ & $0.82 / 0.65$ & $0.67 / 0.40$ & $0.42 / 0.35$ & $3.67 / 2.84$ \\
II & $0.97 / 0.84$ & $0.54 / 0.50$ & $0.70 / 0.57$ & $0.50 / 0.37$ & $0.33 / 0.33$ & $3.05 / 2.61$ \\
III & $1.17 / 1.14$ & $0.58 / 0.48$ & $0.73 / 0.67$ & $0.75 / 0.67$ & $0.47 / 0.40$ & $3.71 / 3.36$ \\
IV & $1.14 / 0.97$ & $0.53 / 0.40$ & $0.75 / 0.72$ & $0.82 / 0.58$ & $0.46 / 0.43$ & $3.70 / 3.11$ \\
\hline
\end{tabular}


Table 2. Spination of legs of Nungia epigynalis [3 (NSMT-Ar 12510) \& 우 (NSMTAr 12511), dorsal/ventral].

\begin{tabular}{|c|c|c|c|}
\hline Leg & Femur & Tibia & Metatarsus \\
\hline $\mathrm{I}^{\star}$ & $0-0-1-2 p / 0$ & $0 / 2-2-1 p-2$ & $0 / 2-2$ \\
\hline I우 & $0-0-1-2 p / 0$ & $0 / 2-2-0-2$ & $0 / 2-2$ \\
\hline II $\hat{\sigma}^{-1}$ & $0-0-1-2 p / 0$ & $0 / 1 \mathrm{r}-1 \mathrm{r}-2$ & $0 / 2-2$ \\
\hline II우 & $0-0-1-2 p / 0$ & $0 / 0-1 \mathrm{r}-2$ & $0 / 2-2$ \\
\hline III ${ }^{\star}$ & $0-0-1-3 / 0$ & $2-2 / 0-2$ & $2-2 / 0-2$ \\
\hline III우 & $0-0-1-1 \cdot 1 \mathrm{p} / 0$ & $2-2 / 0-2$ & $2-2 / 0-2$ \\
\hline IV & $0-0-1-3 / 0$ & $2-2 / 2-2$ & $0-2 / 0-2$ \\
\hline IV우 & $0-0-1-1-1 \mathrm{p} / 0$ & $2-2 / 0-2$ & $0-2 / 0-2$ \\
\hline
\end{tabular}

Male palp (Figs. 4-7). Embolus small with broad basal part, retrolateral tibial apophysis bold.

Female. Body length 5.67, prosoma length 2.34, width 1.90 , height 1.17; opisthosoma length 3.00 , width 1.58 . Eye fields: width of eye row I 1.66, width of eye row III 1.67, length of eye row 1.07, ALE-PME length 0.53, AME diameter 0.85; ratio ALE/AME 0.56, ALE/PLE 1.13, PME/PLE 0.28. Length and spination of legs as shown in Tables 1 and 2 respectively. Leg III longest.

Coloration and markings (Fig. 2) almost same as male, but femora, patellae and tibiae of leg I dark brown.

Chelicera with promarginal two teeth and retromarginal single tooth.

Epigynum (Fig. 8) with one central opening and internal genitalia clearly visible through the surface; the fundamental shape of internal structure seems to be the same as that of holotype.

Distribution. Vietnam, China and Japan (known from Ishigakijima Island and Iriomotejima Island, Okinawa Pref.)

Remarks. The appearance of Nungia epigynalis resembles that of Bavia sexpunctata (Doleschall 1859) known from Iriomotejima Island (Tanikawa 1993), but can be easily distinguished from each other by the shapes of prosoma and opisthosoma ( $N$. epigynalis has prosoma whose frontal end as wide as middle portion, while $B$. sexpunctata has rounder prosoma; $N$. epigynalis has long elliptical opisthosoma, while that of $B$. sexpunctata anteriorly swollen), retromarginal teeth of chelicera (1-2 teeth in $N$. epigynalis, 4-7 teeth in B. sexpunctata), spinnerets color (dark brown in N. epyginalis, light brown in B. sexpunctata) and the structures of male palp (embolus slender in $N$. epyginalis, hook-like and stout in $B$. sexpunctata) and epigynum $(N$. epyginalis has a central opening on epigynum, while $B$. sexpunctata has a longitudinal median ridge).

\section{Genus Pancorius Simon 1902}

Type species: Pancorius dentichelis (Simon 1899).

This genus consists of a total of 30 species from Southeast Asia to Japan, except for a single species Pancorius crassipes (Karsch 1881) from the Palearctic region (Prószyński 2012). The quadrangle of eyes is subparallel and the posterior of prosoma not much narrower, retromarginal tooth simple (Simon 1903; Cameron \&
Wijesinghe 1993). In male, the eye row I is wider than the eye row III, but the female eye row III wider than eye row I.

\section{Pancorius submontanus Prószyński 1992 \\ [Japanese name: Yamaneko-haetori]}

(Figs. 9-15)

Pancorius submontaus Prószyński 1992, pp. 191-193, figs. 113124 (주우).

Specimens examined. Ishigakijima Island, Okinawa Pref., Japan: 10, Mt. Omotodake, 20-IV-1978, T. Tsutsumi leg. (NSMT-Ar 12519). Iriomotejima Island, Okinawa Pref., Japan: 1ð`, Otomi, 10-VIII-1987, A. Tanikawa leg. (NSMT-Ar 12517); 1우. same locality, 9-VI-1996, T. Sasaki leg. (NSMT-Ar 12518); 10, Urauchi, 28-XII-1986, A.

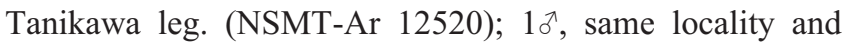
collector, 23-XII-1991 (NSMT-Ar 12521); 1우, Komi, 1-V1990, A. Tanikawa leg. (NSMT-Ar 12522).

Description. A male specimen (NSMT-Ar 12517) and a female specimen (NSMT-Ar 12518).

Male. Body length 5.67; prosoma length 2.81, width 2.29 , height 1.92; opisthosoma length 2.84 , width 1.83 . Eye fields: width of eye row I 2.11, width of eye row III 2.03, ALE-PME length 1.34, half length of eye row 0.67, AME diameter 0.67; ratio ALE/AME 0.55, ALE/PLE 1.05, PME/PLE 0.26. Length and spination of legs as shown in Tables 3 and 4 respectively. Leg I longest.

Palp (Figs. 12-14) with a thin and medium-sized embolus and membranous outgrowth on lower tegulum; retrolateral tibial apophysis with a single projection.

Coloration and markings (Fig. 9). Prosoma orange brown with white hairs, with surroundings of eyes black, and with brown setae and white hairs. Clypeus orange brown with white hairs. Sternum pale brown with brown hairs. Labium, maxillae and chelicerae pale brown marginally paler. Opisthosomal dorsum in ethanol gray with dark marking as in Fig. 9, with many brown setae on anterior margin. Venter of opisthosoma gray. All legs orange brown, except femora and patella of leg I and femora of leg II prolaterally black.

Chelicera (Fig. 10) with a single tooth on retromargin and promargin respectively.

Female. Body length 8.52; prosoma length 3.34, width 


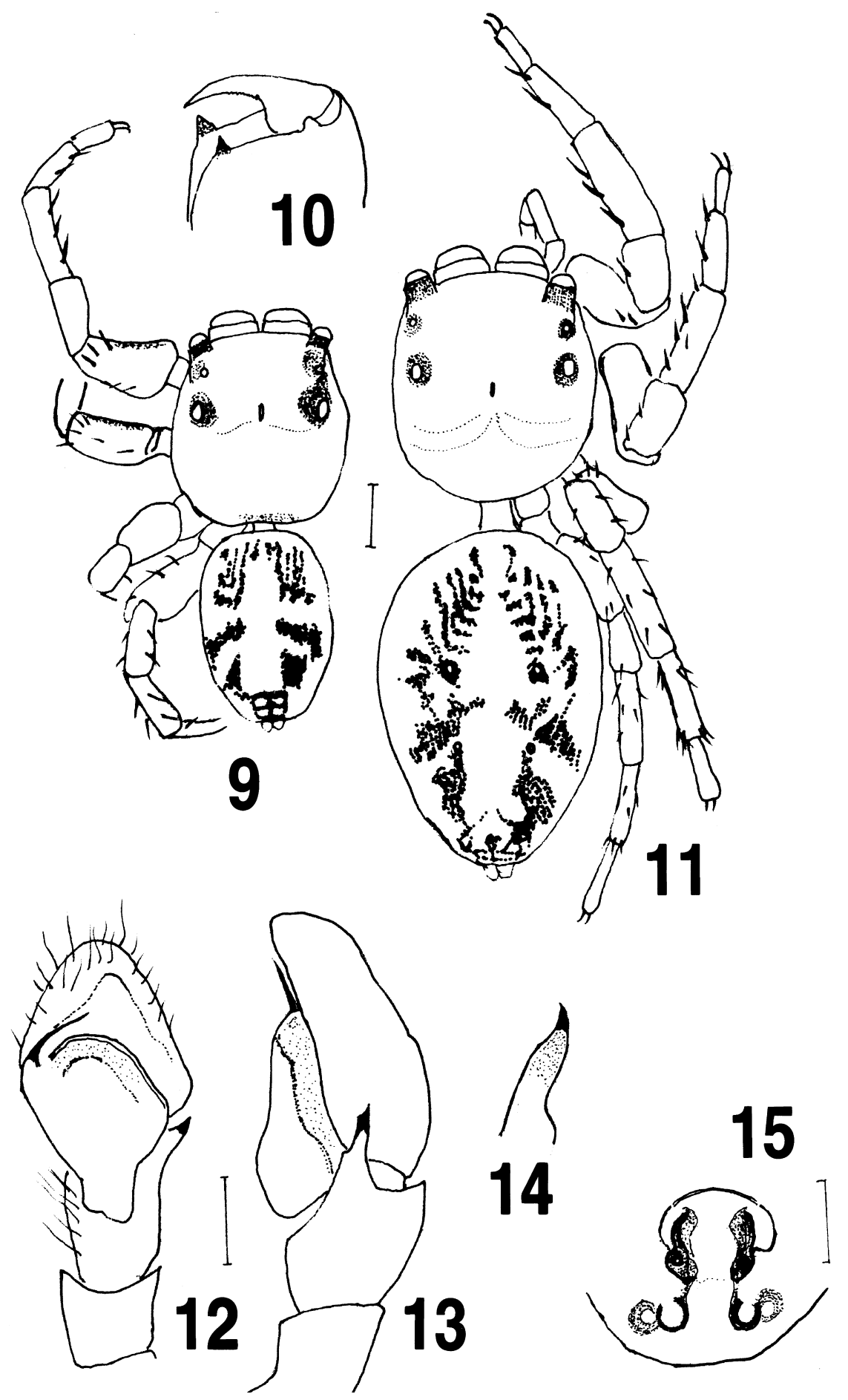

Figs. 9-15. Pancorius submontanus Prószyński 1992, male (9-10, 12-14, NSMT-Ar 12517) and female (11, 15, NSMT-Ar 12518) from Otomi, Iriomotejima Island. 9, 11, habitus, dorsal views; 10, left chelicera, showing cheliceral teeth, ventral view; 12-13, left palp, ventral (12) and retrolateral (13) views; 14, retrolateral tibial apophysis of palp, retrolateral view; 15, epigynum, ventral view. Scales $=1.0 \mathrm{~mm}(9$, $11) ; 0.2 \mathrm{~mm}(12-13,15)$.

Table 3. Length of leg segments of Pancorius submontanus [ð̊ (NSMT-Ar 12517)/9 (NSMT-Ar 12518), in mm].

\begin{tabular}{ccccccc}
\hline Leg & Femur & Patella & Tibia & Metatarsus & Tarsus & Total \\
\hline I & $2.13 / 2.29$ & $1.08 / 1.46$ & $1.88 / 1.92$ & $1.17 / 1.17$ & $0.48 / 0.79$ & $6.84 / 7.63$ \\
II & $1.71 / 2.09$ & $0.92 / 1.29$ & $1.33 / 1.54$ & $0.92 / 1.04$ & $0.50 / 0.67$ & $5.46 / 6.63$ \\
III & $2.25 / 2.29$ & $0.92 / 1.25$ & $1.33 / 1.67$ & $1.33 / 1.63$ & $0.63 / 0.83$ & $6.51 / 7.67$ \\
IV & $2.09 / 2.29$ & $0.83 / 1.08$ & $1.42 / 1.71$ & $1.42 / 1.67$ & $0.63 / 0.67$ & $6.42 / 7.42$ \\
\hline
\end{tabular}


Table 4. Spination of legs of Pancorius submontanus [ð (NSMT-Ar 12517) \& 우 (NSMT-Ar 12518), dor$\mathrm{sal} /$ ventral].

\begin{tabular}{|c|c|c|c|c|}
\hline Leg & Femur & Patella & Tibia & Metatarsus \\
\hline $\mathrm{I}^{\pi}$ & $0-1-1-1 \cdot 2 \mathrm{p} 1 \mathrm{r} / 0$ & $2-1 p-0 / 0$ & $2-0-2-0 / 0-2-2-2$ & $0 / 2-2$ \\
\hline I우 & $0-1-1-1 \cdot 2 \mathrm{p} 1 \mathrm{r} / 0$ & $2-2-0 / 0$ & $0 / 2-2-2-2$ & $0-2-2 / 2-2$ \\
\hline II $\sigma^{\lambda}$ & $0-1-1-1 \cdot 2 \mathrm{p} 1 \mathrm{r} / 0$ & $2-2-0 / 0$ & $2-2-2-0 / 2-1 r-0-2$ & $2-2 / 2-2$ \\
\hline II우 & $0-1-1-1 \cdot 2 \mathrm{p} 1 \mathrm{r} / 0$ & $2-2-0 / 0$ & $1 p-1 p-0 / 2-1 r-2-2$ & $0-1 p-1 p / 2-2$ \\
\hline III & $0-1-1 \cdot 1 \mathrm{p}-1 \cdot 2 \mathrm{p} 1 \mathrm{r} / 0$ & $2-2-0 / 0$ & $2-2-2-0 / 0-2-0-2$ & $2-2 / 2-2 p 2 r$ \\
\hline III 우우 & $0-1-1-1 \cdot 2 \mathrm{p} 1 \mathrm{r} / 0$ & $2-2-0 / 0$ & $2-2-2-0 / 0-1 p-2$ & $2-2 / 2-2 p 2 r$ \\
\hline IVळ & $0-1-1-3 / 0$ & $2-2-0 / 0$ & $2-2-2-0 / 0-2-0-2$ & $2-2-2 / 0-2-0-2 p 2 r$ \\
\hline $\mathrm{IV}$ 우 & $0-1-1-3 / 0$ & $2-2-0 / 0$ & $0-2-2-0 / 0-1 p-0$ & $2-2-2 / 0-2-0-2 p 2 r$ \\
\hline
\end{tabular}

2.92, height 2.42; opisthosoma length 4.96, width 3.50. Eye fields: width of eye row I 2.47, width of eye row III 2.54, length of eye row 1.60, ALE-PME length 0.77, AME diameter 1.23; ratio ALE/AME 0.54, ALE/PLE 1.14, PME/PLE 0.25. Length and spination of legs as shown in Tables 3 and 4 respectively. Leg III longest.

Coloration and markings (Fig. 11). Prosoma orange brown without white hairs. Clypeus, sternum, labium, maxillae, chelicerae and opisthosoma same as male. All legs yellowish brown.

Epigynum and internal genitalia (Fig. 15). Epigynum consists of crescent genital opening on upper region and centrally sclerotized pockets, sometimes with a mating plug or plugs in the pockets.

Distribution. India, Japan (known from Ishigakijima Island and Iriomotejima Island, Okinawa Pref.)

Remarks. This species can be distinguished from the Japanese congener, Pancorius crassipes (Karsch 1881), by the male palp with membranous outgrowth on lower tegulum, while tegulum is mostly discal in P. crassipes; and by the epigynum with a crescent ridge anteriorly situated, while anterior ridge is divided into two parts in P. crassipes. Japanese male specimens are smaller $(5.67 \mathrm{~mm}$ in body length) than Indian specimens of the original description (9.13 $\mathrm{mm}$ in body length) (Prószyński 1992).

\section{Genus Thyene Simon 1885}

\section{Type species: Thyene imperialis (Rossi 1846)}

This genus consists of a total 42 species and four subspecies mainly from Afrotropical Region, a few species from Oriental Region and only type-species found in Palearctic (Jastrzębski 2006). Prosoma somewhat round and its length is subequal to prosoma width, eye quadrangle square or rectangular (Ono et al. 2009). The line of anterior eyes recurved, and tibiae and metatarsi of all legs armed with short and thin spines (Simon 1903). Opisthosoma elongated, with a longitudinal yellowish brown stripe on dorsum, lateral parts blackish brown (except $T$. imperialis). Embolus of male palp long and thin, curving around bulbus in one or two circles. Bulbus round in ventral view, with a membranous outgrowth on upper or lower part. Copulatory ducts of female internal genitalia relatively long, twisted into several circles (Xie \& Peng 1995).

\author{
Thyene orientalis Żabka 1985 \\ [Japanese name: Ajiamikado-haetori]
}

(Figs. 16-25)

Thyene orientalis Żabka, 1985, p. 454, figs. 632-635 ( $\left.{ }^{\circledR}\right)$; Peng et al. 1993, p. 244, figs. 869-873 (ð`); Xie \& Peng 1995, pp. 107-108, figs. 6A-E ( $\left.{ }^{\prime}\right)$.

Specimens examined. Ishigakijima Island, Okinawa Pref., Japan: 1우, Mt. Omotodake, 20-V-1975, H. Makihara leg. (NSMT-Ar 12528). Iriomotejima Island, Okinawa Pref., Japan: 10 ${ }^{\Uparrow}$, Komi, 27-III-1987, A. Tanikawa leg. (NSMT-Ar 12523); 1ㅇ, Shirahama, 27-VII-1963, Y. Miyatake leg. (NSMT-Ar 12524); 1ㅊ1우, Otomi, 4-V-1984, A. Tanikawa leg. (NSMT-Ar 12525); 10, same locality and collector, 29-III-1988 (NSMT-Ar 12526); 1우, Sonai, 30-III1988, A. Tanikawa leg. (NSMT-Ar 12527).

Description. Male specimens (NSMT-Ar 12523, 12525, 12526) and female specimens (NSMT-Ar 12524, 12527, 12528).

Male. Measurements of NSMT-Ar 12523, range of the other specimens (NSMT-Ar 12525 \& 12526) in brackets. Body length 7.20 [6.34-7.20], prosoma length 3.25 [3.023.25 ], width 2.59 [2.40-2.59], height 1.75 [1.58-1.75]; opisthosoma length 3.46 [3.25-3.67], width 1.79 [1.791.98]. Eye fields: width of eye row I 2.14 [1.96-2.14], width of eye row III 2.18 [2.03-2.18], length of eye row 1.28 [1.28-1.34], ALE-PME length 0.56 [0.56-0.63], AME diameter 1.07 [1.04-1.07]; ratio ALE/AME 0.50 [0.460.50], ALE/PLE 1.00 [1.00], PME/PLE 0.20 [0.20-0.25]. Length and spination of legs of NSMT-Ar 12523 as shown in Tables 5 and 6 respectively. Leg IV longest.

Coloration and markings (Fig. 16). Prosoma orange brown with dense white setae, with a pair of longitudinal brown bands, and with brown margins. Posterior eyes with black surrounds with white hairs. Anterior part of prosoma with white setae and brown setae. Clypeus brown with brown setae, maxillae and labium brown with pale margins. Sternum orange brown with white hairs. Opisthosoma brown with a pair of dark brown bands with translucent hairs and brown setae, central part covered with dense white hairs, anterior margin with brown setae and white setae. Venter of opisthosoma gray with a black central streak, both sides black with translucent setae and hairs. Frontal legs 

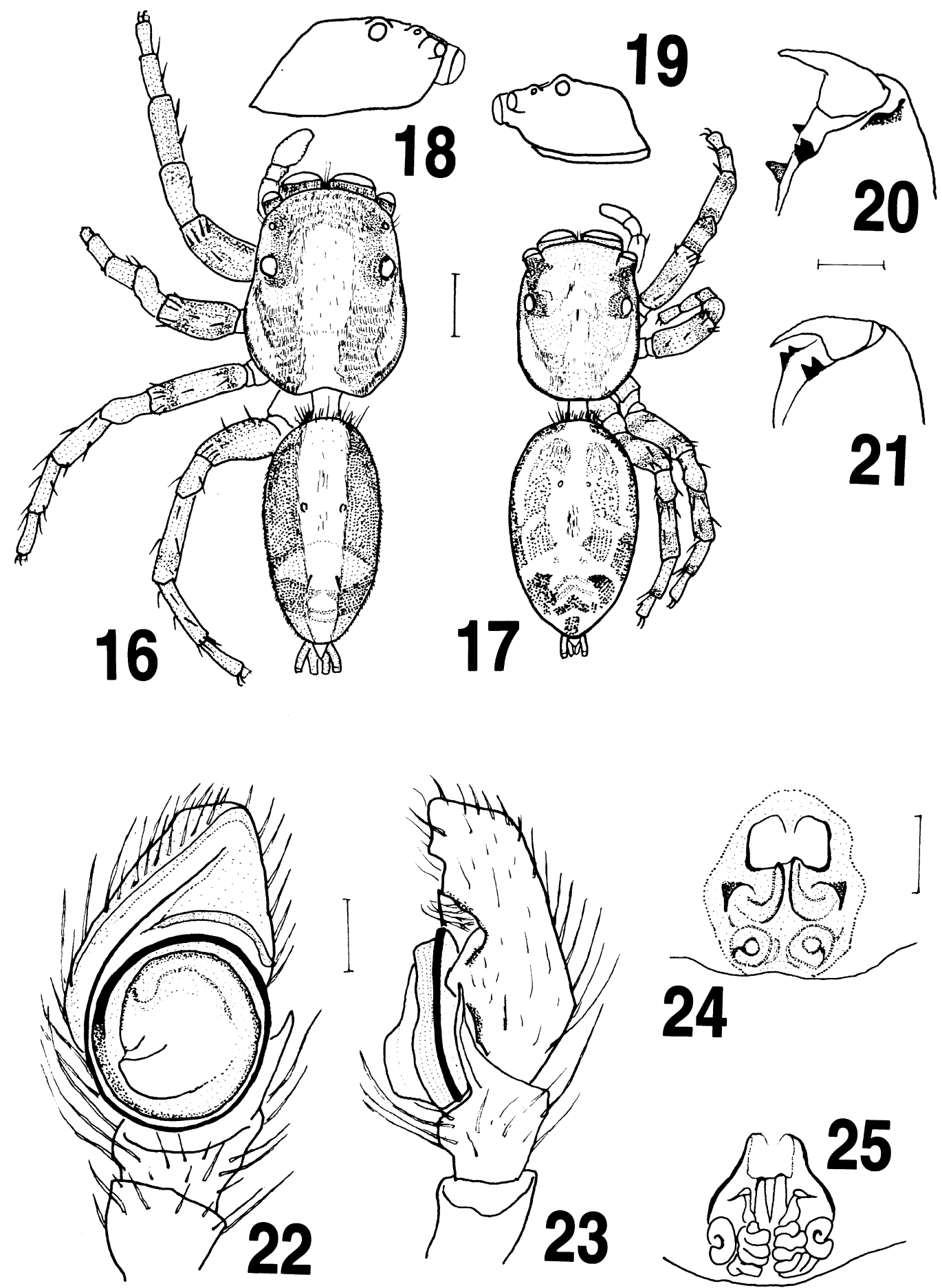

Figs. 16-25. Thyene orientalis Żabka 1985, male (16, 18, 20, 22-23, NSMT-Ar 12523), female (17, 19, 24, NSMT-Ar 12526; 21, NSMTAr 12528; 25, NSMT-Ar 12527). 16-17, habitus, dorsal views; 18-19, prosoma, right lateral (18) and left lateral (19) views; 20-21, left chelicera, showing cheliceral teeth, ventral views; 22-23, left palp, ventral (22) and retrolateral (23) views; 24, epigynum, ventral view; 25, internal genitalia, dorsal view. Scales $=1.0 \mathrm{~mm}(16,17), 0.2 \mathrm{~mm}\left(20^{-25}\right)$.

Table 5. Length of leg segments of Thyene orientalis [^ (NSMT-Ar 12523)/우 (NSMT-Ar 12524), in mm].

\begin{tabular}{ccccccc}
\hline Leg & Femur & Patella & Tibia & Metatarsus & Tarsus & Total \\
\hline I & $0.75 / 1.17$ & $0.84 / 0.65$ & $1.17 / 0.75$ & $0.92 / 0.63$ & $0.53 / 0.50$ & $4.21 / 3.71$ \\
II & $1.67 / 1.12$ & $0.90 / 0.63$ & $0.99 / 0.75$ & $0.84 / 0.50$ & $0.50 / 0.42$ & $4.90 / 3.42$ \\
III & $1.80 / 1.37$ & $0.94 / 0.70$ & $1.09 / 0.84$ & $1.17 / 0.89$ & $0.52 / 0.50$ & $5.51 / 4.29$ \\
IV & $1.67 / 1.42$ & $0.89 / 0.68$ & $1.34 / 1.00$ & $1.42 / 1.07$ & $0.67 / 0.50$ & $5.98 / 4.68$ \\
\hline
\end{tabular}


Table 6. Spination of legs of Thyene orientalis [^ (NSMT-Ar 12523) \& 우 (NSMT-Ar 12524), dorsal/ventral].

\begin{tabular}{|c|c|c|c|c|}
\hline Leg & Femur & Patella & Tibia & Metatarsus \\
\hline $\mathrm{I} \hat{\sigma}^{\lambda}$ & $1-1-1 \cdot 2 \mathrm{p} 1 \mathrm{r} / 0$ & $2 / 0$ & $1 \mathrm{p}(1 \mathrm{r})-1 \mathrm{p}(1 \mathrm{r})-2-0 / 2-2-2$ & $2-2 / 2-2$ \\
\hline $\mathrm{I}$ 우 & $1-1-1 \cdot 2 \mathrm{p} 1 \mathrm{r} / 0$ & $1 \mathrm{p} / 0$ & $1 p-1 p-2-0 / 2-2-2$ & $2-2 / 2-2$ \\
\hline $\mathrm{II}_{3}$ & $1-1 \cdot 1 \mathrm{r}-1 \cdot 2 \mathrm{p} 2 \mathrm{r} / 0$ & $2 / 0$ & $2(1 \mathrm{r})-2-2 / 2-2-2$ & $2-2 / 2-2$ \\
\hline II우 & $1-1-1 \cdot 2 \mathrm{p} 2 \mathrm{r} / 0$ & $1 \mathrm{p} / 0$ & $1 \mathrm{p}-1 \mathrm{p}-2-0 / 2-2-2$ & $2-2 / 2-2$ \\
\hline III ${ }^{\curvearrowright}$ & $1-1 \cdot 1 \mathrm{p}-1 \cdot 2 \mathrm{p} 2 \mathrm{r} / 0$ & $2 / 0$ & $3-2-2-2 / 0-2-2$ & $2-0-2 / 2-1 p$ \\
\hline III우 & $1-1 \cdot 1 \mathrm{p}-1 \cdot 2 \mathrm{p} 2 \mathrm{r} / 0$ & $2 / 0$ & $3-2-2-0 / 0-1 \mathrm{p}-2$ & $2-0-2 / 2-2 \mathrm{p} 2 \mathrm{r}$ \\
\hline IV え & $1-1 \cdot 1 \mathrm{p}-1 \cdot 2 \mathrm{p} 2 \mathrm{r} / 0$ & $2 / 0$ & $3-2-2-2 / 2-2$ & $2-2-2 / 2-2 \mathrm{p} 2 \mathrm{r}$ \\
\hline IV우 & $1-1--1 \cdot 2 \mathrm{p} 2 \mathrm{r} / 0$ & $2 / 0$ & $3-2-2-0 / 0-1 p-2$ & $2-2-2 / 2-2 \mathrm{p} 2 \mathrm{r}$ \\
\hline
\end{tabular}

brown and darker than hind legs; femora, tibiae and metatarsi of frontal legs blackish brown, femora and metatarsi of hind legs black and annulated.

Chelicera (Fig. 21). Retromargin with a tooth distally bifurcated; promargin with three teeth, but one of them situated dorsolaterally invisible from ventral.

Palp (Figs. 22-23) with long and thin embolus and a small membranous outgrowth on lower part of bulbus.

Female. Measurement NSMT-Ar 12524, range of the other specimens (NSMT-Ar 12525, 12527, 12528) in brackets. Body length 6.17 [5.67-6.17]; prosoma length 2.50 [2.21-2.50], width 1.96 [1.73-1.96], height 1.21 [1.171.25]; opisthosoma length 3.50 [3.04-3.50], width 2.17 [2.04-2.34]. Eye fields: width of eye row I 1.76 [1.60$1.76]$, width of eye row III 1.76 [1.60-1.76], length of eye row 1.07 [1.01-1.09], ALE-PME length 0.48 [0.45-0.53], AME diameter 0.92 [0.85-0.92]; ratio ALE/AME 0.52 [0.47-0.52], ALE/PLE 1.00 [1.00-1.06], PME/PLE 0.17 [0.17-0.27]. Length and spination of NSMT-Ar 12524 as shown in Tables 5 and 6 respectively. Leg IV longest.

Coloration and markings almost same as those of male (Fig. 17). Prosoma orange brown with white setae not densely as male, with a pair of longitudinal brown bands with translucent hairs, and brown margin. Posterior eyes with black surrounds with white hairs. Clypeus orange brown with brown setae. Chelicerae brown. Maxillae, and labium orange brown. Sternum orange brown with white hairs. Opisthosoma yellowish brown, with a pair of dark brown bands interrupted by a few pale cheverons and with white hairs and brown setae but fallen out in ethanol, with brown setae fallen out on center, and with brown setae and white setae on anterior margin. Venter of opisthosoma gray with a weak black central streak, and both sides black with translucent hairs and brown hairs. Leg I orange brown except femora prolaterally dark and tibiae darkly annulated. Leg II orange brown except femora and tibiae darkly annulated. Legs III and IV orange brown except femora and tibiae blackly annulated, metatarsi black distally.

Chelicera (Fig. 21) with a retromarginal tooth distally bifurcated and two promarginal teeth.

Epigynum and internal genitalia (Figs. 24-25). Genital opening situated frontally on epigynum, seminal receptacles with complex copulatory ducts.

Distribution. Vietnam, China, Taiwan and Japan (known from Iriomotejima Island and Ishigakijima Island,
Okinawa Pref.).

Remarks. Thyene orientalis is distinguished from the type species of the genus, $T$. imperialis, by the following points: (1) in T. orientalis male palp has a membranous outgrowth on lower part of bulbus, while the outgrowth is situated prolaterally in $T$. imperialis, (2) male prosoma of $T$. orientalis is not so trapezoidal as that of $T$. imperialis, and (3) T. orientalis has complex copulatory ducts in female internal genitalia, while copulatory ducts are rather simple in T. imperialis.

\section{Acknowledgments}

I wish to express my thanks to Dr. Akio Tanikawa, the late Dr. Chiyoko Okuma and Mr. Takeshi Sasaki for offering the specimens, to Mr. Tatsumi Suguro for offering photographs of live individuals of Nungia epigynalis and Pancorius submontanus, and to Dr. Hirotsugu Ono and Dr. Takahide Kamura for scientific advice.

\section{References}

Cameron, H. D. \& Wijesinghe, D. P. 1993. Simon's keys to the salticid groups, translated with an introduction and indices. Peckhamia, 3: 1-26.

Jastrzębski, P. 2006. Salticidae from the Himalayas. The Genus Thyene Simon 1885 (Arachnida: Araneae). Acta Arachnol., 55: 1-4.

Ono, H., Ikeda, H \& Kono, R. 2009. Salticidae. Pp. 558-588. In: Ono, H. (ed.) The Spiders of Japan: with keys to the families and genera and illustrations of the species. Tokai Univ. Press, Kanagawa, xvi $+738 \mathrm{pp}$.

Peng, X. J., Xie, L. \& Xiao, X. 2003. Salticidae in China. Hunan Normal Univ. Press, Changsha, 290 pp.

Prószyński, J. 1992. Salticidae (Araneae) of India in the collection of the Hungarian National History Museum in Budapest. Ann. Zool., Wars., 44: 165-227.

Prószyński, J. 2012. Monograph of the Salticidae (Araneae) of the world. 1995-2011. On internet. <http://www.miiz.waw.pl/salticid/ main.htm>

Simon, E. 1903. Histoire Naturelle des Araignees. 2 (3-4), 738 pp.

Song, D. X., Zhu, M. S. \& Chen, J. 1999. The Spiders of China Hebei Science and Technology Publishing House, 640 pp. \& 4 pls.

Tanikawa, A. 1993. Two newly recorded spiders from Japan, Bavia sexpunctata (Doleschall, 1859) and Rhene setipes Żabka, 1985 (Araneae: Salticidae). Acta Arachnol., 42: 13-19.

Xie, L. \& Peng, X. 1995. Spiders of the genus Thyene Simon (Araneae: Salticidae) from China. Bull. Br. Aarachnol. Soc., 10: 104-108.

Żabka, M. 1985. Systematic and zoogeographic study on the family Salticidae (Araneae) from Viet-Nam. Ann. Zool., Warz., 36: 197485 .

Received February 8, 2013 / Accepted June 1, 2013 